

\title{
Self-employment by gender in the EU: convergence and clusters
}

João Ricardo Faria

Florida Atlantic University

Department of Economics

jfaria@fau.edu

\section{Luis Gil-Alana}

University of Navarra

Department of Economics

alana@unav.es

\author{
Juan Carlos Cuestas \\ Tallinn University of Technology, Eesti Pank \& UJI \\ IEI \& Department of Economics \\ cuestas@uji.es
}

\author{
Estefania Mourelle \\ University of A Coruna \\ Department of Economics \\ emourelle@udc.es
}

$2020 / 22$

\begin{abstract}
This paper studies the convergence of self-employment by gender in the European Union, through tests for the order of integration and cluster analysis, in order to investigate the occurrence of two types of convergence: between genders and among European countries. The paper makes two contributions to the literature: 1) theoretically, it provides useful insights into the macroeconomic determinants of self-employment; 2) methodologically, it uses unit roots, fractional integration and cluster analysis to assess convergence. The empirical results point at mixed evidence of convergence, but with clear differences between the core and the periphery of Europe.
\end{abstract}

Keywords: Self-employment, gender, European Union, convergence, cluster analysis

JEL classification: J16, J24, O57 


\title{
Self-employment by gender in the EU: convergence and clusters
}

\author{
João Ricardo Faria ${ }^{\mathrm{a}}$, Juan Carlos Cuestas ${ }^{\mathrm{b}, \mathrm{c}, \mathrm{d}}$, Luis Gil-Alana ${ }^{\mathrm{e}}$, Estefania Mourelle ${ }^{\mathrm{f}}$ \\ ${ }^{a}$ Department of Economics, Florida Atlantic University, USA \\ ${ }^{b}$ Department of Economics and IEI, Jaume I University, Spain. \\ ${ }^{c}$ Department of Economics and Finance, Tallinn University of Technology, Estonia. \\ ${ }^{d}$ Research Unit, Eesti Pank, Estonia. \\ ${ }^{e}$ Department of Economics, University of Navarra \\ ${ }^{f}$ Department of Economics, University of A Coruna
}

\begin{abstract}
This paper studies the convergence of self-employment by gender in the European Union, through tests for the order of integration and cluster analysis, in order to investigate the occurrence of two types of convergence: between genders and among European countries. The paper makes two contributions to the literature: 1) theoretically, it provides useful insights into the macroeconomic determinants of self-employment; 2) methodologically, it uses unit roots, fractional integration and cluster analysis to assess convergence. The empirical results point at mixed evidence of convergence, but with clear differences between the core and the periphery of Europe.
\end{abstract}

Keywords: Self-employment, gender, European Union, convergence, cluster analysis.

JEL classification: $\mathrm{J} 16, \mathrm{~J} 24$, O57.

\begin{abstract}
Acknowledgements
Juan Carlos Cuestas acknowledges the financial support from the MINEIC-AEI-FEDER ECO2017-85503-R and ECO2017-83255-C3-3-P projects both of them from 'Ministerio de Economía, Industria y Competitividad' (MINEIC), `Agencia Estatal de Investigación' (AEI) Spain and 'Fondo Europeo de Desarrollo Regional' (FEDER), and the UJI project UJI-B2019-15. The first of these projects is also acknowledged by Luis A. Gil-Alana.
\end{abstract}

*Corresponding author. Email: juancarlos.cuestas@uji.es 


\section{Introduction}

The European Commission recognizes the importance of entrepreneurship which, under the Europe 2020 Strategy, has promoted self-employment through the European Process Microfinance Facility, the Employment and Social Innovation Programme and the European Social Fund [https://ec.europa.eu/growth/smes/promoting-entrepreneurship/action-plan/]. Over the years, many European countries have made efforts to increase the number of entrepreneurs and to improve their performance, through educational and training programmes together with support measures such as reducing administrative barriers to setting up in business and the provision of start-up subsidies (Andersson and Wadensjö, 2007). These efforts have significant payoffs in terms of economic growth and job creation, (Bendick and Egan, 1987; Goetz et al., 2012; Parker, 2018).

Moreover, self-employment is responsible for a significant share of employment in Europe, accounting for nearly 14 per cent of workers (Hatfield, 2015). A number of recent studies have pointed to the relative growth of self-employment in a number of EU countries over the crisis period (Fondeville et al., 2015), associated with an increase in self-employment among women and in agriculture in some EU-13 countries (Baldassarini, 2015, and Weixel, 2014)ํ․

This paper studies whether there is convergence in self-employment by gender in the European Union. The study may help the EU and member countries to devise policies to boost entrepreneurship and reduce gender gap. The paper addresses the issue in two complementary ways. First, it proposes a new theoretical approach, with macroeconomic foundations of microeconomic decisions of entrepreneurs. Secondly, it empirically implements a number of techniques, some new in the entrepreneurship literature such as cluster analysis, to test the

\footnotetext{
${ }^{1}$ Fritsch et al. (2015) show that Germany experienced a unique rise in the level of self-employment in the first two decades following unification. The factors driving the overall level of self-employment are demographic developments, the shift towards service sector employment, and a larger share of population holding a tertiary degree.
} 
model. We aim to find evidence of two types of convergence: between genders and among European countries.

The paper presents a stylized macro model that provides, in a simple framework, macrofoundations of entrepreneurial activity. We show that entrepreneurship depends on a mix of macro and micro variables. Curiously, gender differences in entrepreneurship are independent of macro variables, only microeconomic differences matter. Self-employment between males and females is being driven by differences between education and risk attitudes, for males and females, while purely macro variables amplify them.

In order to test these theoretical findings, the paper uses a number of techniques to assess convergence, namely, unit root tests, fractional integration and cluster analysis. The time series analysis of convergence finds, in general, mixed evidence of convergence. The cluster analysis results find four clusters, when forming groups of countries with similarities in terms of GDP per capita, educational attainment, globalization and retirement. The results highlight the difference between core and peripheral countries in Europe. The empirical analysis shows that the main factors pointed out by the theoretical framework influence self-employment in Europe.

The paper makes two contributions to the literature: 1) theoretically, it provides a model that yields useful insights into the macroeconomic determinants of self-employment; 2) methodologically, it combines panel unit roots, cointegration and cluster analysis in order to group, identify and assess the convergence hypothesis of self-employment by gender in Europe.

The organization of the paper is as follows. In the next section we go through the most relevant works within the field. The theoretical model and the empirical approach are presented in section 3. Section 4 presents the results, and section 5 the concluding remarks. 


\section{Brief Literature Review}

The literature on the determinants of self-employment is vast; it considers micro and macro motives, and factors at several levels including individual, firm, industry, and country (e.g., Terjensen et al., 2016). Education has a major role (Evans and Leighton, 1989). Highly educated people are more likely to be pulled into self-employment than those with a lower level of education (Svaleryd, 2014). Wealth, either from inherited or accumulated assets along with access to finance are also strong determinants of becoming self-employed (Holtz-Eakin et al., 1993; Joulfaian and Wilhelm, 1994; Faria and Wu, 2012). Indeed, the availability of finance and development of the financial industry generally are key factors in enabling people to start and grow their own businesses (Block et al., 2018). Risk attitudes also matter; several studies show that entrepreneurs are less-risk averse than non-entrepreneurs (Brown et al., 2006).

Marital status, number of children and family background play an important role in determining self-employment. For instance, parental self-employment both increases the fraction of time that offspring spend in self-employment and reduces the age at which they enter in it (Dunn and Holtz-Eakin, 2000, and Niitykangas and Tervo, 2005). Personal reasons, a research area pioneered by Knight (1921), are also significant; they include control over working conditions, freedom to choose the place and time of work, preference for independence, self-fulfilment, and an associated higher level of responsibility. Cultural factors influencing entrepreneurship, such as the social image of entrepreneurs, are becoming an important topic of research (Ferreira and Fernandes, 2015). Some studies, like Verheul et al. (2004) evidence that the same factors underlie male and female entrepreneurship.

Macroeconomic factors affecting self-employment and entrepreneurship are generally associated with employment, economic growth and the management of factors of production, such as technology creation and implementation, knowledge growth, innovation and spillovers 
(Goel and Goktepe-Hulten, 2013). Empirical literature on the relationship between entrepreneurial activity and economic growth found that entrepreneurship plays a different role in countries in different stages of economic development. Wennekers and Thurik (1999) suggested the existence of a U-shaped relationship between the number of self-employed and stages of economic development2. Similarly, van Stel et al. (2005) found that entrepreneurial activity by early stage entrepreneurs affects economic growth, but this effect depends upon the level of per capita income. Entrepreneurship also has a significantly positive impact on GDP per capita, exports/GDP, and patents per population, and a negative impact on unemployment (Cumming et al., 2014).

Macroeconomic issues such as regional factors (Fernandes et al., 2015), institutional context (Boudreaux, 2017), unemployment and business cycles, and their impact on entrepreneurship are also studied. For example, the influential paper of Kollinger and Thurik (2012) finds that entrepreneurship Granger-causes the cycles of the world economy, and that the entrepreneurial cycle is positively affected by the national unemployment cycle. Faria et al. (2009) estimated the periodicity of the cycles for unemployment and entrepreneurship in the US, the UK, Spain and Ireland is between 5 and 10 years (see also Faria et al., 2010).

Notwithstanding the size of the literature, there have been, however, few attempts to analyse the behavior of self-employment rate difference between male and female entrepreneurs and whether they converge both at country and at European levels. Our paper relates to Dawson et al. (2014) and Saridakis et al. (2019), which are articles that tackle each of those problems (see also Monfort el al., 2013).

\footnotetext{
${ }^{2}$ Acs (2006) and Thurik, (2009) claim a link between economic growth and entrepreneurship but definitely not specifically for self-employment.
} 
We seek to contribute to the literature by filling the gap on studies that compare the behavior of self-employment in different countries (in particular those one belonging to economic areas, Saridakis et al., 2019) by focusing the attention on gender differences. Thus, in this paper we analyse convergence among self-employment rates between male and female by means of unit root tests and fractional integration. Then, we perform a cluster analysis to classify European countries into groups according to their behavior vis $\grave{a}$ vis based on a group of major determinants: GDP per capita, educational attainment, globalization index, retirement, tax burden and internet access. To give our work some theoretical substance we present a stylized macro model that yields two types of determinants of self-employment: typical macro variables such as GDP per capita, tax burden, net exports, as well as micro choice variables, such as risk attitudes, captured by retirement preferences, and educational attainment.

\section{The Theoretical Model and the Empirical Approach}

\section{3a. The Model}

The model combines a macroeconomic framework with specific microeconomic assumptions concerning entrepreneurship.

Output, $Y$, is determined by a production function that depends on technology, $\tau$, physical capital, $K$, human capital, $H$, and Labor, $L$ :

$$
Y=F(\tau, K, H, L)=(\tau K)^{a} H^{b} L^{1-a-b} .
$$

Technology is associated with entrepreneurship, since entrepreneurs, $E$, have to find new ways to gain or to create and develop markets to survive, as stressed by Schumpeter (1934). In our analysis, it does not matter what the type of entrepreneur is ${ }^{3}$, the only relation that we need is that the entrepreneur is the agent responsible for technology:

\footnotetext{
${ }^{3}$ Technology can be imitative or research-based as emphasized by Minniti and Lévesque (2010). The type of entrepreneur [imitator or creator] is more important depending on the type of country (Goel and Ram, 1994, and
} 


$$
\tau=\tau(E), \tau_{E}>0
$$

In order to simplify the model, assume a linear function as in Faria (2015):

$$
\tau=\tau(E)=E
$$

This assumption is clearly reasonable when Schumpeterian entrepreneurship is involved, but it may not be appropriate when self-employment is used as a proxy of entrepreneurship. In most underdeveloped world the average self-employed is not innovative at all, hence the number of self-employed is not a good indicator of technology (Henrekson and Sandaji, 2019) ${ }^{4}$. However, as we are studying the case of European countries, which are richer in human capital, $H=h E L$, we can use it as an additional source of entrepreneurship, perhaps more closely related to selfemployment.

Introducing (2') into (1) and rewriting it in per capita terms we have:

$$
\frac{Y}{L}=y=(k E)^{a}(h E)^{b}=k^{a} h^{b} E^{a+b},
$$

where $k=K / L$ and $h E=H / L$.

Based on the permanent income theory (Friedman, 1957), we assume that household consumption $C$ is a linear combination of present consumption, and anticipated future consumption. Present consumption is an increasing function of disposable income $(Y-T)$, where $T$ is household taxes, and anticipated future consumption $A$ (e.g., Faria and McAdam, 2013; Monteiro and Turnovsky, 2016), that reflects retirement preferences and risk attitudes, and may depend on expected future income:

$$
C=\alpha\left[C_{0}+c(Y-T)\right]+(1-\alpha) A
$$

\footnotetext{
Gong and Keller, 2003). Rich countries would have more creators, while entrepreneurs in poor countries would more likely be imitators.

${ }^{4}$ Henrekson and Sanandaji (2014) conclude that small business activity does not measure entrepreneurship, and the rate of billionaire entrepreneurship (considered to have high-impact/ to be of Schumpeterian type) negatively correlates (cross-county) with SE.
} 
where $c \in(0,1)$ and $\alpha \in[0,1]$. Note that for $\alpha=1$, we have the usual Keynesian consumption function .

Private saving is the difference between disposable income and consumption:

$$
S_{h}=Y-T-C=Y-T-\alpha\left[C_{0}+c(Y-T)\right]-(1-\alpha) A .
$$

Public saving corresponds to government revenue, given by household taxes $T$, minus government spending $G$ :

$$
S_{g}=T-G
$$

Net investments $\Delta K$ depend on the difference of total investment $I$ and capital depreciation $\delta K$ :

$$
\Delta K=I-\delta K
$$

From national income accounts net exports NX corresponds to the difference between saving and investment:

$$
N X=S-I=S_{h}+S_{g}-I
$$

Note that the system of equations (3) - (8) determine six endogenous variables. If we assume that $Y, L, T, G, A, C_{0}, \Delta K$, are given, then this system determines $E, C, I, N X, S_{g}, S_{h}$.

In order to highlight how this macroeconomic model influences entrepreneurship, let us solve it for $E$. Plugging eqs. (3) - (7) into eq. (8) and solving for entrepreneurship $E$, yields:

$$
E=\left[\frac{\delta L}{\left\{Y-T-\alpha\left[C_{0}+c(Y-T)\right]-(1-\alpha) A+T-G-\Delta K-N X\right\}}\right]^{\frac{a}{a+b}}\left(\frac{y}{h^{b}}\right)^{\frac{1}{a+b}}
$$

According to Equation (9), entrepreneurship E, or the ratio of entrepreneurship per labor force $E / L$, depends on a mix of macro and micro variables. The macro variables that influence entrepreneurship are: total income $Y$ [which links entrepreneurship to business cycle and unemployment, if one takes into account Okun's law (e.g., Prachowny, 1993)], income per capita $y$, tax burden $T$, infra-structure $G$ [proxy given by communications such as internet 
access], net investments, $\Delta K$, and globalization $N X$. The micro variables that affect entrepreneurial activity are: retirement preferences [reflecting risk attitudes] that affect anticipated future consumption $A$, and human capital per capita $h$ [educational attainment, which are proxied by primary or tertiary education],

From Equation (9) one can disentangle purely macro variables such as $Y, L, \Delta K, N X, C_{0}, T$ and $G$ from the ones that are impacted by individual choice, such as education $h$ and risk attitudes [captured by the anticipated future consumption, $A$ ]. This leads us to speculate that the difference in self-employment between males and females is associated with the micro variables. Self-employment between males and females is being driven by differences between education and risk attitudes, for males and females, while the remaining purely macro variables amplify them.

Since the above model is a very simple approximation of the macro determinants of entrepreneurship, it lacks micro foundations, i.e., optimizing individual agents. In particular, gender preferences affecting educational choice is critical to determine an educational attainment threshold to differentiate self-employment entrepreneurs and fully formal entrepreneur. The same holds true with regard to risk attitudes. Of course, the further development of the model along these lines is beyond the objective of this paper and is left for future research.

\section{3b. Empirical Approach on the Convergence Hypothesis}

We analyse the convergence hypothesis between male and female self-employment rates. For that, we make sure of the theoretical concept of sigma-convergence (SC) by Barro and Salai-Martin (1991) and the long run convergence by Bernard and Durlauf (1995). Their proposals relate directly to the analysis of the order of integration of variables and unit roots. Hence, as a first step we analyse convergence between self-employment rates between male and female by 
means of unit root tests and fractional integration. With fractional integration we estimate the following model:

$$
\mathrm{y}_{t}=\beta_{0}+\beta_{1} t+x_{t} ; \quad(1-L)^{d} x_{t}=u_{t}, \quad t=0,1, \ldots, T
$$

where $y_{t}$ is the observed time series; $\beta_{0}$ and $\beta_{1}$ are unknown coefficients referring respectively to an intercept and a linear time trend; we suppose $x_{t}$ to be $\mathrm{I}(\mathrm{d})$ where $d$ can be any real value, and $u_{t}$ is $\mathrm{I}(0)$ expressed in terms of a white noise process. Fractional integration provides us with further flexibility when analysing the order of integration of variables, since it breaks the dichotomy between $\mathrm{I}(1)$ and $\mathrm{I}(0)$ by allowing any real number for the order of integration. Hence, if $d<0.5$ the process is mean reverting and stationary, whereas for $0.5 \leq d<1$ the process is non-stationary but mean reverting. This is the advantage of fractional integration; one can characterise a series as slow mean reverting. We conduct the estimation here of the differencing parameter $\mathrm{d}$ based on the Whittle function expressed in the frequency domain as suggested in Dahlhaus (1989) and using a version of the test of Robinson (1994) that is very convenient, in the sense that it is based on the Lagrange Multiplier principle and it does not impose stationarity as an a priori condition. Moreover, its limiting distribution is standard normal and thus, we can easily obtain the confidence band of the non-rejection values of $d .^{5}$

Second, we test for the existence of convergence clubs in the same fashion as Monfort el al. (2013). As previously mentioned, Faria et al. (2009) find that the relationship between entrepreneurship and unemployment is cyclical. As far as unemployment rates are also synchronised amongst countries (see also Faria et al., 2010), there should be some degree of synchronisation between different countries self-employment and its male-female difference. The results from this analysis could potentially have important policy implications at the EU level. The more evidence there is of convergence or bigger clubs of convergence, the easier the

\footnotetext{
${ }^{5}$ See Gil-Alana and Robinson (1997) for the specific functional form of the testing approach employed here.
} 
task of applying policies is in order to enhance equality in the rates of self-employment between sexes.

Going deeper into the study, we observe that the behavior of self-employment is different across the different European countries; in addition, the effect of certain socioeconomic variables such as GDP per capita or educational attainment on entrepreneurship can be of relevance and should be taken into account. Then, it would be of interest to classify the countries into different groups with common characteristics in terms of self-employment and other variables that may influence it; this would unveil the distinct behavior of the countries regarding self-employment by gender and its determinants.

So as to do this, we resort to the cluster analysis, as this multivariate technique makes it possible to classify a certain number of elements - in this case, countries - into groups according to their behavior vis à vis certain variables; here we propose GDP per capita, educational attainment, globalization, retirement, tax burden and internet access according to our theoretical model. The aim is to form groups, named clusters, so that the elements belonging to a group are similar (i.e., there is homogeneity) but different form the ones of another group; in order to do so, the calculation of distances between the elements is needed. In particular, we utilize the hierarchical algorithm in order to cluster the countries. We find this technique an especially illustrative and clear one to assess convergence among countries. 


\section{Analysis and results}

\section{4a. Time series analysis of convergence}

For the empirical part of the paper we use self-employment rates over active population for seventeen EU countries. The selection of countries is due to data availability. The data comes from Eurostat and we use annual observations spanning 1995-2018 for three measures; total self-employment, self-employment with employees and without employees. This distinction will help us to check whether the type of self-employment matters in terms of convergence. ${ }^{6}$

In Figure 1 we present the difference in total male-female self-employment rates. We observe that the greatest difference between genders appears in Greece and the smallest in Luxembourg.

In Figure 2, we present the difference in male-female self-employment rates for the case of self-employed with employees. Not only Greece, but also Italy has the highest difference, in contrast with Austria and Luxembourg.

In Figure 3, we plot the time series for the difference in male-female self-employment rates, without employees. We find that Ireland, along with Greece are the countries with the highest differences, and once again Austria and Luxembourg appear as having the smallest differences.

\footnotetext{
${ }^{6}$ Eurostat defines a self-employed person as "the sole or joint owner of the unincorporated enterprise (one that has not been incorporated i.e. formed into a legal corporation) in which he/she works, unless they are also in paid employment which is their main activity (in that case, they are considered to be employees)" (retrieved from https://ec.europa.eu/eurostat/statistics-explained/index.php/Glossary:Self-employed on 22/06/2020).
} 
Figure 1: Difference in self-employment rate male-female (total)

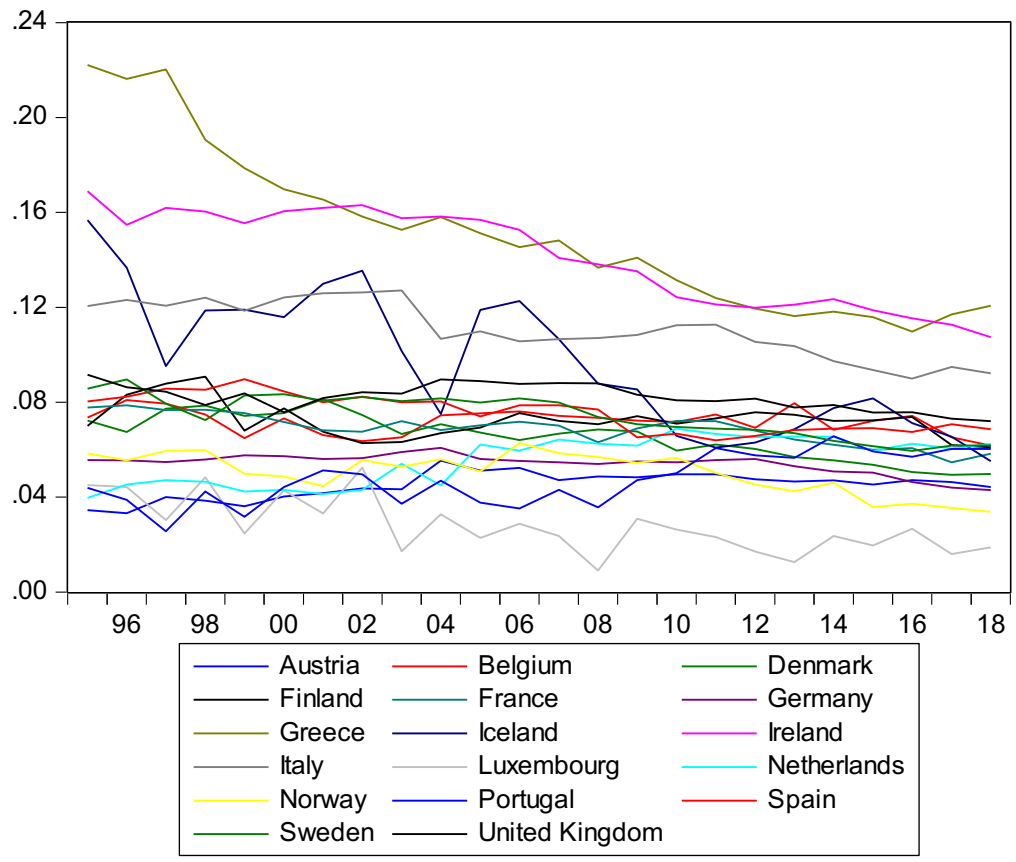

Figure 2: Difference in self-employment rate male-female (with employees)

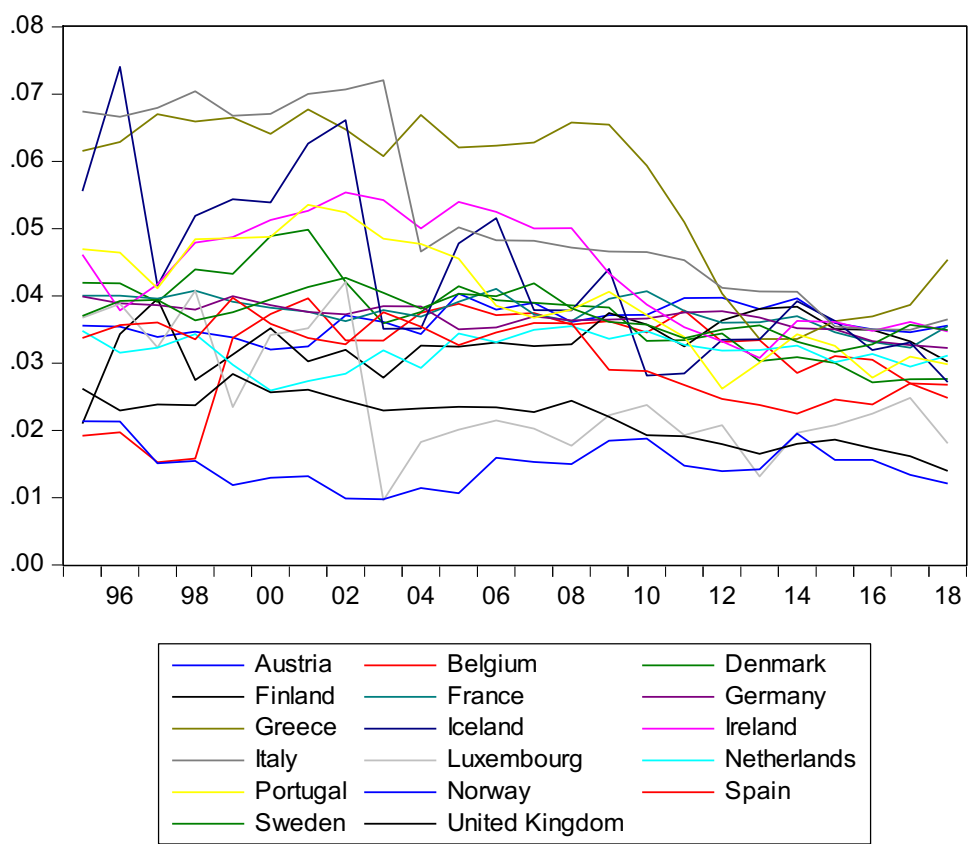




\section{Figure 3: Difference in self-employment rate male-female (without employees)}

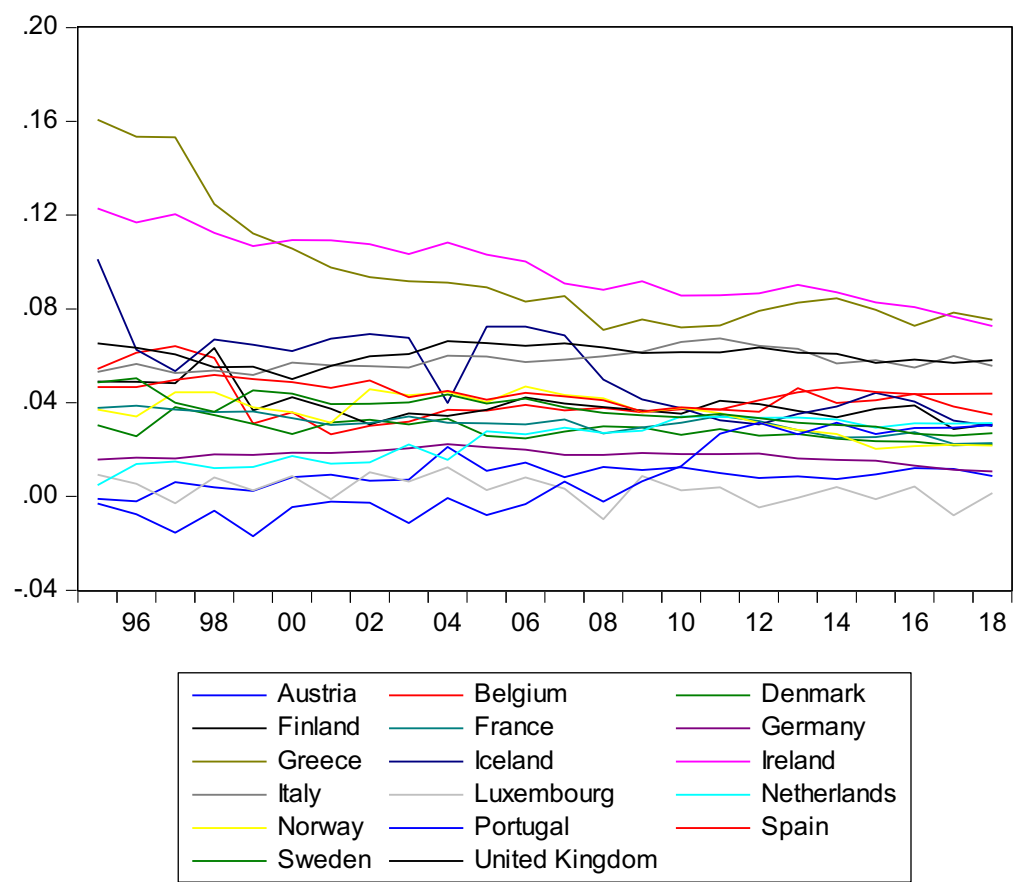

In Table 1, we show the results of applying the Ng and Perron (2001) unit root tests, with only one lag due to the shortage of data, for the data in Figure 1. From Table 1, we can highlight that there is only some evidence of convergence for Belgium and Finland.

In Table 2 we show the results of the unit root tests for the case of self-employed with employees. We are able to reject the null only for Austria, Finland and the Netherlands. In Table 3, we show the results of the unit root tests for the case of self-employed without employees, finding that only Finland shows some evidence of convergence. ${ }^{7}$

As a complementary analysis, we apply fractional integration techniques for the order of integration of the difference between the male-female self-employment rates. As earlier

\footnotetext{
${ }^{7}$ Performing other standard unit root methods like Dickey and Fuller (ADF, 1979) and Phillips and Perron (PP, 1988) we obtain similar evidence in favor of nonstationarity $I(1)$ in the majority of the cases.
} 
explained, this methodology is more general than the standard one based on unit roots, and that only considers integer degrees of differentiation. Moreover, many authors have shown the low power of the unit root tests if the true data generating process is fractionally integrated (Diebold and Rudebusch, 1991; Hassler and Wolters, 1994; Lee and Schmidt, 1996; etc.).

We first computed the estimated values of $d$ (and the 95\% confidence bands) for the three standard cases of i) no deterministic terms (i.e., $\left.\beta_{0}=\beta_{1}=0\right)$, ii) an intercept $\left(\beta_{1}=0\right)$, and iii) an intercept with a linear time trend ( $\beta_{0}$ and $\beta_{1}$ estimated from the data), and selected the model for each series based on the t-values of the estimated coefficients of the differenced processes. The selected models are marked in bold in the tables. Across Tables $4-6$, we present the detailed results of the estimations, and in Table 7 we present a summary of the results.

Table 1: Unit root test results, difference total male-female self-employment

\begin{tabular}{lllll}
\hline & \multicolumn{1}{c}{$M Z a$} & $M Z t$ & \multicolumn{1}{c}{$M S B$} & $M P T$ \\
\hline Austria & -1.98556 & -0.98480 & 0.49598 & 12.2090 \\
Belgium & $-8.64257^{* *}$ & $-1.86615^{*}$ & 0.21592 & $3.58668^{* *}$ \\
Denmark & -1.37311 & -0.55417 & 0.40359 & 11.6888 \\
Finland & $-8.00861^{*}$ & $-1.89205^{*}$ & $0.23625^{*}$ & $3.44601^{*}$ \\
France & -1.39970 & -0.54574 & 0.38990 & 11.3025 \\
Germany & 1.42035 & 0.60624 & 0.42683 & 19.1068 \\
Greece & -0.80518 & -0.45152 & 0.56078 & 18.7202 \\
Iceland & 0.26723 & 0.16127 & 0.60348 & 25.8591 \\
Ireland & 1.24835 & 0.99101 & 0.79385 & 48.1433 \\
Italy & -1.26782 & -0.53277 & 0.42023 & 12.3575 \\
Luxembourg & 0.07513 & 0.07618 & 1.01401 & 58.1275 \\
Netherlands & -0.65666 & -0.43438 & 0.66150 & 24.2949 \\
Norway & -0.46394 & -0.19120 & 0.41212 & 13.9733 \\
Portugal & -2.55255 & -0.99087 & 0.38819 & 8.93151 \\
Spain & -2.27775 & -0.96662 & 0.42438 & 10.0293 \\
Sweden & -1.04647 & -0.47269 & 0.45170 & 13.8414 \\
UK & -2.66444 & -0.82068 & 0.30801 & 7.96558 \\
\hline
\end{tabular}

Note: The symbols * and ** indicate rejection of the null of unit root at the 10 and $5 \%$ significance level, respectively. In the first row, the M-tests are the modified tests proposed by Ng and Perron (2001). Critical values can be found in Ng and Perron (2001, Table 1). 
Table 2: Unit root test results, difference male-female self-employment with employees

\begin{tabular}{lllll}
\hline & MZa & \multicolumn{1}{c}{ MZt } & MSB & MPT \\
\hline Austria & $-5.86345^{*}$ & $-1.70902^{*}$ & 0.29147 & $4.18791^{*}$ \\
Belgium & -3.24283 & -1.27048 & 0.39178 & 7.55132 \\
Denmark & -0.94958 & -0.43906 & 0.46237 & 14.4602 \\
Finland & -5.52449 & $-1.66186^{*}$ & 0.30082 & 4.43519 \\
France & -2.52238 & -1.01118 & 0.40088 & 9.14437 \\
Germany & -0.96857 & -0.32349 & 0.33399 & 10.7246 \\
Greece & -1.06467 & -0.61967 & 0.58203 & 18.4685 \\
Iceland & -1.07939 & -0.52268 & 0.48424 & 14.8023 \\
Ireland & -1.77107 & -0.80136 & 0.45247 & 11.8754 \\
Italy & -1.10481 & -0.54102 & 0.48969 & 14.9040 \\
Luxembourg & -1.22510 & -0.65612 & 0.53557 & 16.0485 \\
Netherlands & -5.66209 & $-1.66312^{*}$ & 0.29373 & 4.38176 \\
Norway & -5.34365 & -1.53602 & 0.28745 & 4.83321 \\
Portugal & -1.55657 & -0.68982 & 0.44317 & 12.2302 \\
Spain & -2.61092 & -0.99588 & 0.38143 & 8.74081 \\
Sweden & -4.10951 & -1.38870 & 0.33792 & 6.00766 \\
UK & -0.31648 & -0.12264 & 0.38750 & 13.4284 \\
\hline
\end{tabular}

Note: The symbol * indicates rejection of the null of unit root at the $10 \%$ significance level. In the first row, the M-tests are the modified tests proposed by Ng and Perron (2001). Critical values can be found in Ng and Perron (2001, Table 1).

Table 3: Unit root test results, difference male-female self-employment without employees

\begin{tabular}{lllll}
\hline & \multicolumn{1}{c}{$\mathrm{MZa}$} & \multicolumn{1}{c}{$\mathrm{MZt}$} & \multicolumn{1}{c}{ MSB } & \multicolumn{1}{c}{ MPT } \\
\hline Austria & -3.35541 & -1.27689 & 0.38054 & 7.28491 \\
Belgium & 0.02663 & 0.03274 & 1.22950 & 81.3198 \\
Denmark & -2.68951 & -0.96297 & 0.35805 & 8.36411 \\
Finland & $-8.08279^{*}$ & $-1.89843^{*}$ & $0.23487^{*}$ & $3.42907^{*}$ \\
France & -1.73226 & -0.59813 & 0.34529 & 9.77942 \\
Germany & -2.48410 & -0.79357 & 0.31946 & 8.30769 \\
Greece & -0.17892 & -0.13798 & 0.77117 & 34.4210 \\
Iceland & -3.31124 & -1.07644 & 0.32509 & 7.19174 \\
Ireland & 1.05481 & 0.67682 & 0.64166 & 32.7095 \\
Italy & -5.04106 & -1.58277 & 0.31398 & 4.87136 \\
Luxembourg & -0.60247 & -0.49679 & 0.82459 & 34.5300 \\
Netherlands & -0.20329 & -0.14968 & 0.73626 & 31.7918 \\
Norway & -1.74798 & -0.70028 & 0.40062 & 10.8087 \\
Portugal & -1.29176 & -0.59029 & 0.45696 & 13.3213 \\
Spain & -3.41039 & -1.29936 & 0.38100 & 7.17923 \\
Sweden & -1.67151 & -0.63948 & 0.38257 & 10.5978 \\
UK & -4.69460 & -1.47931 & 0.31511 & 5.31962 \\
\hline
\end{tabular}

Note: The symbol * indicates rejection of the null of unit root at the $10 \%$ significance level. In the first row, the M-tests are the modified tests proposed by $\mathrm{Ng}$ and Perron (2001). Critical values can be found in Ng and Perron (2001, Table 1). 
Table 4: Estimated values of $d$ for the total self-employment

\begin{tabular}{|c|c|c|c|}
\hline Series & No terms & With intercept & With time trend \\
\hline Austria & $0.72(0.15,1.09)$ & $0.66(0.47,0.96)$ & $0.67^{+}(0.47,0.96)$ \\
\hline Belgium & $0.74(0.18,1.23)$ & $0.04(-0.58,0.72)$ & $0.24(0.58,0.74)$ \\
\hline Denmark & $0.86(0.59,1.22)$ & $0.70 \quad(0.54,0.95)$ & $0.43^{-}(0.54,0.92)$ \\
\hline Finland & $0.88 \quad(0.48,1.37)$ & $0.40(-0.07,0.97)$ & $0.38(-0.07,0.95)$ \\
\hline France & $0.86(0.50,1.34)$ & $0.61 \quad(0.34,1.02)$ & $0.47^{-}(0.34,1.02)$ \\
\hline Germany & $0.81 \quad(0.48,1.23)$ & $1.06(0.80,1.47)$ & $1.08(0.80,1.50)$ \\
\hline Greece & $0.88 \quad(0.57,1.29)$ & $0.90 \quad(0.63,1.29)$ & $0.90^{-}(0.65,1.22)$ \\
\hline Iceland & $0.60(0.31,1.01)$ & $0.39(0.19,1.22)$ & $-0.01^{-}(-0.67,1.22)$ \\
\hline Ireland & $0.80(0.53,1.15)$ & $0.81 \quad(0.64,1.17)$ & $0.79^{-}(0.52,1.24)$ \\
\hline Italy & $0.87(0.57,1.26)$ & $0.72(0.53,1.04)$ & $0.52^{-}(0.01,1.04)$ \\
\hline Luxembourg & $0.35(-0.02,0.62)$ & $0.14(-0.01,0.33)$ & $-0.42^{-}(-0.71,-0.09)$ \\
\hline Netherlands & $0.66(0.18,1.20)$ & $0.59 \quad(0.44,0.78)$ & $\mathbf{0 . 5 0}^{+}(0.27,0.79)$ \\
\hline Norway & $0.75(0.42,1.15)$ & $0.61 \quad(0.38,0.86)$ & $0.59^{-}(0.36,0.87)$ \\
\hline Portugal & $0.88 \quad(0.14,0.79)$ & $0.49 \quad(0.31,0.74)$ & $0.16^{+}(-0.14,0.64)$ \\
\hline Spain & $0.91 \quad(0.63,1.27)$ & $0.75(0.57,1.08)$ & $0.63^{-}(-0.02,1.10)$ \\
\hline Sweden & $0.86(0.54,1.33)$ & $0.67(0.49,1.04)$ & $0.44^{-}(0.15,0.99)$ \\
\hline UK & $0.73(0.36,1.17)$ & $0.59 \quad(0.26,1.03)$ & $0.71^{-}(0.42,1.05)$ \\
\hline
\end{tabular}

Note: The values in parenthesis indicate the $95 \%$ confidence band for the values of d; in bold the selected model for each series. The subscript on the estimated value of $d$ in the last column indicate if the time trend is positive $(+)$ or negative (-).

Table 5: Estimated values of $d$ for the self-employment with employees

\begin{tabular}{|c|c|c|c|}
\hline Series & No terms & With intercept & With time trend \\
\hline Austria & $0.75 \quad(0.32,1.24)$ & $0.48(0.26,0.82)$ & $0.44(0.11,0.82)$ \\
\hline Belgium & $0.81 \quad(0.51,1.26)$ & $0.89(0.59,1.35)$ & $0.89(0.61,1.34)$ \\
\hline Denmark & $0.88 \quad(0.59,1.29)$ & $0.73(0.53,1.23)$ & $0.55^{-}(0.06,1.26)$ \\
\hline Finland & $0.83 \quad(0.42,1.40)$ & $0.08(-0.28,0.47)$ & $-0.20^{+}(-0.86,0.60)$ \\
\hline France & $0.89 \quad(0.53,1.36)$ & $0.50 \quad(0.20,1.05)$ & $0.28^{-}(-0.06,1.03)$ \\
\hline Germany & $0.79 \quad(0.45,1.21)$ & $0.52(0.20,1.11)$ & $0.56^{-}(0.01,1.14)$ \\
\hline Greece & $1.07(0.78,1.48)$ & $1.37(0.98,1.83)$ & $1.37(0.95,1.82)$ \\
\hline Iceland & $0.63(0.31,1.09)$ & $0.30(0.11,0.54)$ & $0.43^{-}(-0.93,0.22)$ \\
\hline Ireland & $0.84(0.62,1.13)$ & $1.02(0.78,1.48)$ & $1.02(0.76,1.53)$ \\
\hline Italy & $0.90(0.64,1.28)$ & $0.71 \quad(0.56,0.98)$ & $0.35^{-}(-0.26,0.95)$ \\
\hline Luxembourg & $0.53(0.24,0.87)$ & $0.27(0.10,0.50)$ & $0.09^{-}(-0.17,0.44)$ \\
\hline Netherlands & $0.71 \quad(0.02,1.19)$ & $0.53(0.19,0.97)$ & $0.59 \quad(0.21,0.97)$ \\
\hline Norway & $0.39(0.03,1.03)$ & $0.53(0.08,1.14)$ & $0.74 \quad(0.25,1.13)$ \\
\hline Portugal & $0.87 \quad(0.62,1.28)$ & $0.77 \quad(0.59,1.16)$ & $0.68^{-}(0.28,1.18)$ \\
\hline Spain & $0.89(0.64,1.25)$ & $0.69(0.53,0.95)$ & $0.51^{-} \quad(0.15,0.95)$ \\
\hline Sweden & $0.92 \quad(0.63,1.32)$ & $0.77 \quad(0.52,1.29)$ & $0.71 \quad(0.29,1.29)$ \\
\hline UK & $0.73(0.46,1.06)$ & $0.61 \quad(0.43,0.96)$ & $0.51^{-}(0.16,1.03)$ \\
\hline
\end{tabular}

Note: The values in parenthesis indicate the $95 \%$ confidence band for the values of d; in bold the selected model for each series. The subscript on the estimated value of $d$ in the last column indicate if the time trend is positive $(+)$ or negative (-). 
Table 6: Estimated values of $\mathbf{d}$ for the self-employment without employees

\begin{tabular}{|c|c|c|c|}
\hline Series & No terms & With intercept & With time trend \\
\hline Austria & $0.24 \quad(0.07,0.58)$ & $0.33(0.11,0.61)$ & $0.34^{+}(0.11,0.64)$ \\
\hline Belgium & $0.78 \quad(0.38,1.30)$ & $0.69(0.29,1.17)$ & $0.74(0.46,1.16)$ \\
\hline Denmark & $0.74 \quad(0.45,1.10)$ & $0.33(0.12,0.62)$ & $-0.30^{-}(-0.81,0.39)$ \\
\hline Finland & $0.66(0.24,1.09)$ & $0.23(-0.05,0.53)$ & $0.14^{-}(-0.15,0.54)$ \\
\hline France & $(0.45,1.28)$ & $0.48 \quad(0.22,0.90)$ & $0.27^{-}(-0.31,0.89)$ \\
\hline Germany & $(0.58,1.29)$ & $1.15(0.93,1.47)$ & $1.16(0.93,1.47)$ \\
\hline Greece & $(0.50,1.24)$ & $1.12(0.60,1.45)$ & $1.10^{-}(0.88,1.36)$ \\
\hline Iceland & $0.47 \quad(0.18,0.83)$ & $0.30(0.11,0.59)$ & $0.02^{-}(-0.44,1.17)$ \\
\hline Ireland & $(0.48,1.18)$ & $0.58(0.42,0.80)$ & $0.24^{-}(-0.36,0.93)$ \\
\hline Italy & $0.76 \quad(0.28,1.19$ & $0.65^{-} \quad(0.46,0.99)$ & $0.63^{-}(0.35,0.99)$ \\
\hline Luxembourg & $-0.14 \quad(-0.36,0.20)$ & $-0.10^{-}(-0.31,0.16)$ & $-0.49^{-}(-0.76,-0.11)$ \\
\hline Netherlands & $0.39(0.29,0.69)$ & $0.54(0.41,0.69)$ & $0.39^{+}(0.16,0.72)$ \\
\hline Norway & $0.85(0.59,1.18)$ & $0.72(0.53,0.99)$ & $0.65^{-}(0.41,0.99)$ \\
\hline Portugal & $0.74(0.59,0.97)$ & $0.72(0.58,0.94)$ & $0.50^{+}(0.15,0.90)$ \\
\hline Spain & $0.88 \quad(0.61,1.26)$ & $0.71(0.49,1.03)$ & $0.69^{-}(0.41,1.04)$ \\
\hline Sweden & $0.78(0.44,1.10)$ & $0.48(0.28,0.74)$ & $-0.02^{-}(-0.44,0.67)$ \\
\hline UK & $0.75(0.26,1.24)$ & $0.96^{-}(0.50,1.36)$ & $0.97^{-}(0.58,1.33)$ \\
\hline
\end{tabular}

Note: The values in parenthesis indicate the $95 \%$ confidence band for the values of $\mathrm{d}$; in bold the selected model for each series. The subscript on the estimated value of $d$ in the last column indicate if the time trend is positive $(+)$ or negative (-).

Table 7: Evidence of convergence with $\mathrm{I}(0)$ or anti-persistence $(\mathrm{I}(\mathrm{d}<0)$, or with $\mathrm{I}(\mathrm{d})$ with $\mathbf{0}<\mathbf{d}<\mathbf{1}$

\begin{tabular}{cccc}
\hline Series & Total & Employees & Without Empl. \\
\hline Austria & $\mathbf{I}(\mathbf{0}<\mathbf{d}<\mathbf{1})$ & $\mathbf{I}(\mathbf{0}<\mathbf{d}<\mathbf{1})$ & $\mathbf{I}(\mathbf{0}<\mathbf{d}<\mathbf{1})$ \\
Belgium & $\mathbf{I}(\mathbf{0})$ & & \\
Denmark & $\mathbf{I}(\mathbf{0}<\mathbf{d}<\mathbf{1})$ & $\mathbf{I}(\mathbf{0})$ & $\mathbf{I}(\mathbf{0})$ \\
Finland & $\mathbf{I}(\mathbf{0})$ & $\mathbf{I}(\mathbf{0})$ & $\mathbf{I}(\mathbf{0})$ \\
France & & & $\mathbf{I}(\mathbf{0})$ \\
Germany & & $\mathbf{I}(\mathbf{0})$ & \\
Greece & & & $\mathbf{I}(\mathbf{0})$ \\
Iceland & $\mathbf{I}(\mathbf{0})$ & $\mathbf{I}(\mathbf{0})$ & $\mathbf{I}(\mathbf{0})$ \\
Ireland & & $\mathbf{I}(\mathbf{0}<\mathbf{d}<\mathbf{1})$ \\
Italy & & $\mathbf{I P}: \mathbf{I}(\mathbf{0}, \mathbf{d}<\mathbf{0})$ \\
Luxembourg & $\mathbf{A P :} \mathbf{I}(\mathbf{d}, \mathbf{d}<\mathbf{0})$ & $\mathbf{I}(\mathbf{0}<\mathbf{d}<\mathbf{1})$ & $\mathbf{I}(\mathbf{0}<\mathbf{d}<\mathbf{1})$ \\
Netherlands & $\mathbf{I}(\mathbf{0}<\mathbf{d}<\mathbf{1})$ & & \\
Norway & & & $\mathbf{I}$ \\
Portugal & $\mathbf{I}(\mathbf{0})$ & $\mathbf{I}(\mathbf{0}<\mathbf{d}<\mathbf{1})$ & \\
Spain & $\mathbf{I}(\mathbf{0})$ & & \\
Sweden & $\mathbf{I}(\mathbf{0}<\mathbf{d}<\mathbf{1})$ & & \\
UK & &
\end{tabular}

Note: AP means antipersistence. Empty boxes mean no convergence. 
From these tables we find that strong evidence of convergence is found in the cases of Luxembourg (anti-persistence), Finland and Iceland (for the three series), and Belgium, Denmark, France. Ireland, Italy, Portugal, Spain and Sweden in some cases. An intermediate level of convergence $(0<\mathrm{d}<1)$ is found in the cases of Austria and the Netherlands (in the three cases) along with Denmark, Italy, Norway, Portugal, Spain and Sweden in some cases. Unit roots (and thus no convergence) is found in Germany and Greece (for the three series) but also in Belgium, Denmark, France, Iceland, Ireland, Italy, Norway, Portugal, Spain, Sweden and the UK.

In general, we find mixed evidence of convergence. These results are in line with those of Saridakis et al. (2019), although they do not differentiate by gender; these authors find that selfemployment presents structural differences in the single European labour market. Thus, in the next subsection we aim to find clusters of convergence in order to find similarities between our target countries.

\section{4b. Cluster analysis}

The cluster analysis is based on grouping the seventeen EU countries according to their similarities in the determinants introduced in Section 2. Thus, we resort to the following variables: GDP per capita (chain linked volumes 2010) and educational attainment (proxied by its percentage at two levels: primary and tertiary) from Eurostat; globalization (measured through the KOF index, KOF Swiss Economic Institute); retirement (proxied by the percentage or population aged 65 and over, with respect to working age population) and communications (proxied by internet access, percentage of all households) from $O E C D$; and tax burden, proxied by tax revenue (percentage of GDP) from the World Bank.

We use the whole time series for each country. In addition, we follow some typical transformations in this type of multivariate analysis. First, we use the logarithm of the original 
variables to solve the existence of outliers in most of them; second, we follow the traditional standardization method because of the different units of measure. The clustering methodology used is the agglomerative hierarchical one, which successively groups the countries according to the distance between them, until only one final cluster exists. Due to the limited number of countries, a maximum of four clusters is allowed.

Figures 4, 5 and 6 depict the clusters of countries with (dis)similarities regarding their values for the difference in total self-employment rate male-female, self-employment with employees and self-employment without employees, respectively. There are four different clusters, numbered from 1 to 4 .

Figure 4: Clusters for the difference in male-female total self-employment

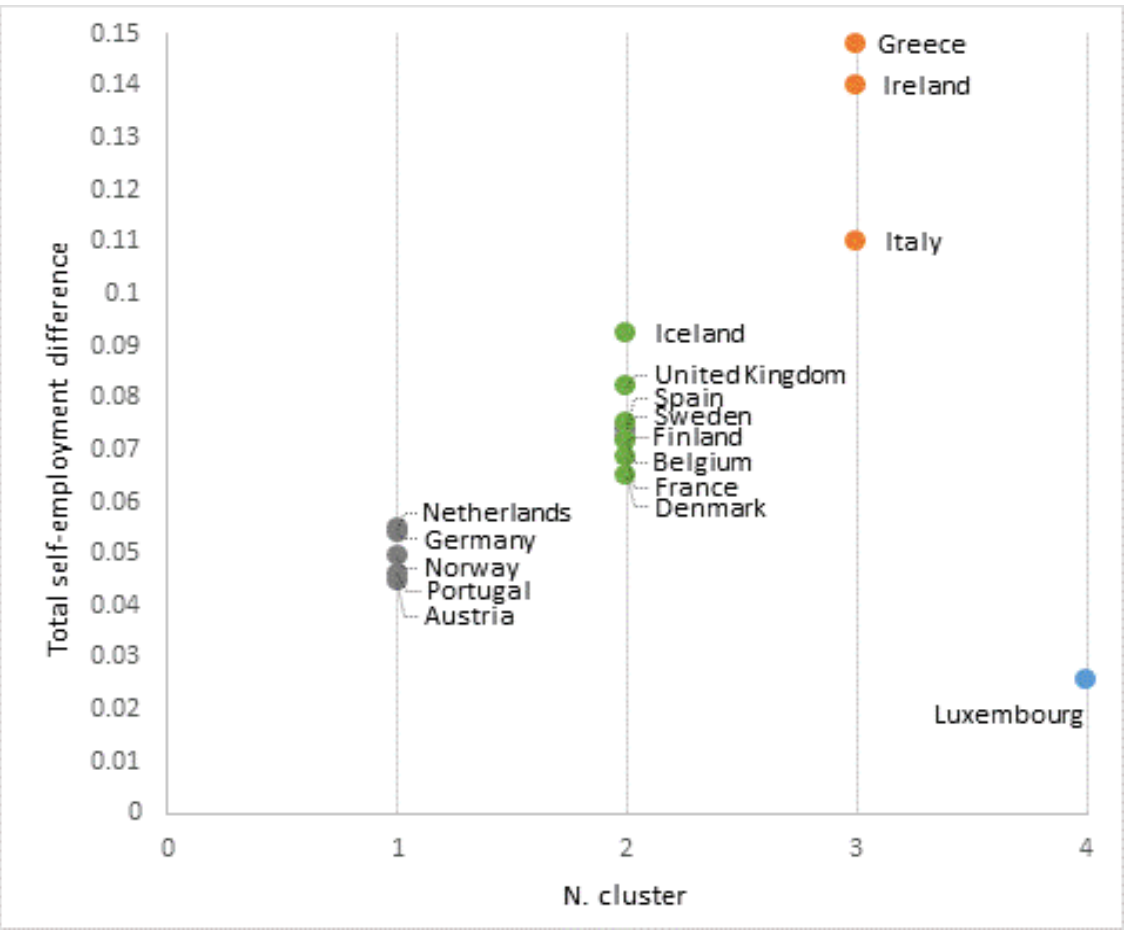


Figure 5: Clusters for the difference in male-female self-employment with employees

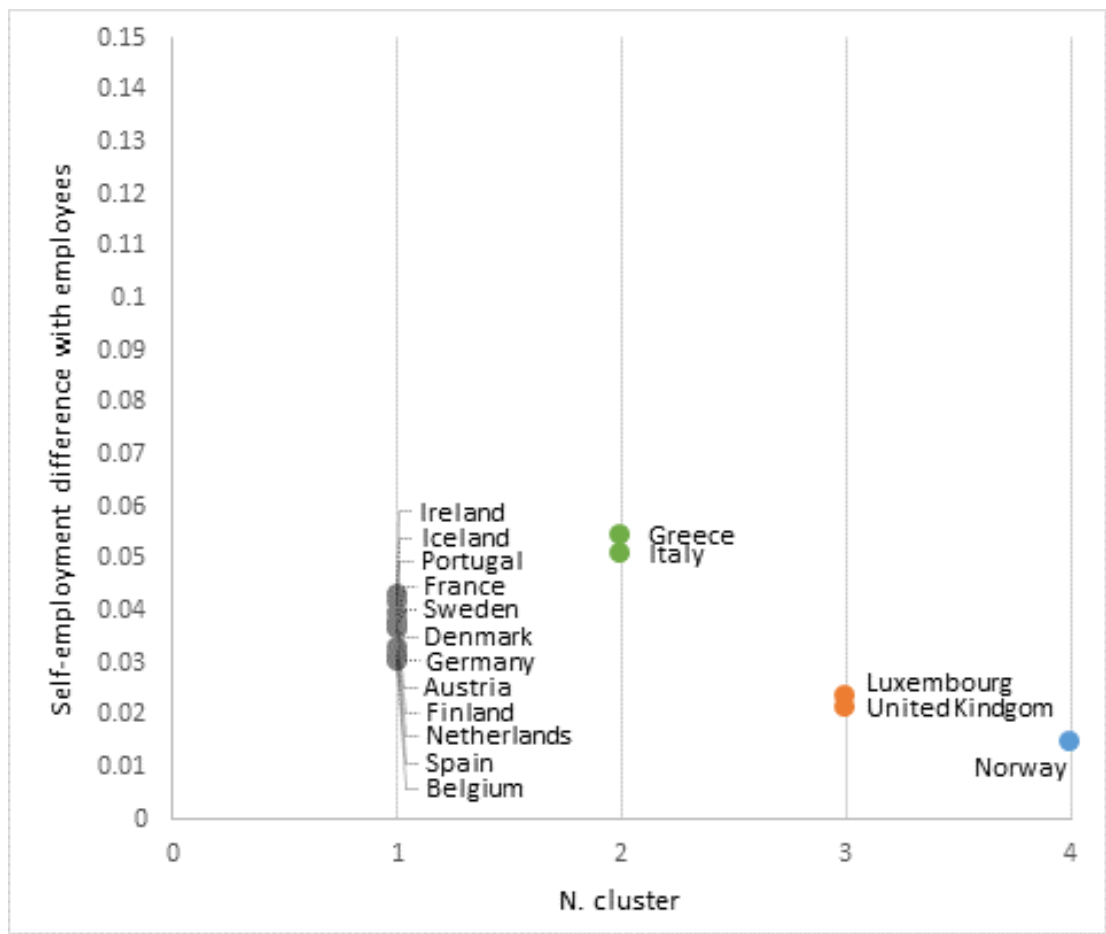

Figure 6: Clusters for the difference in male-female self-employment without employees

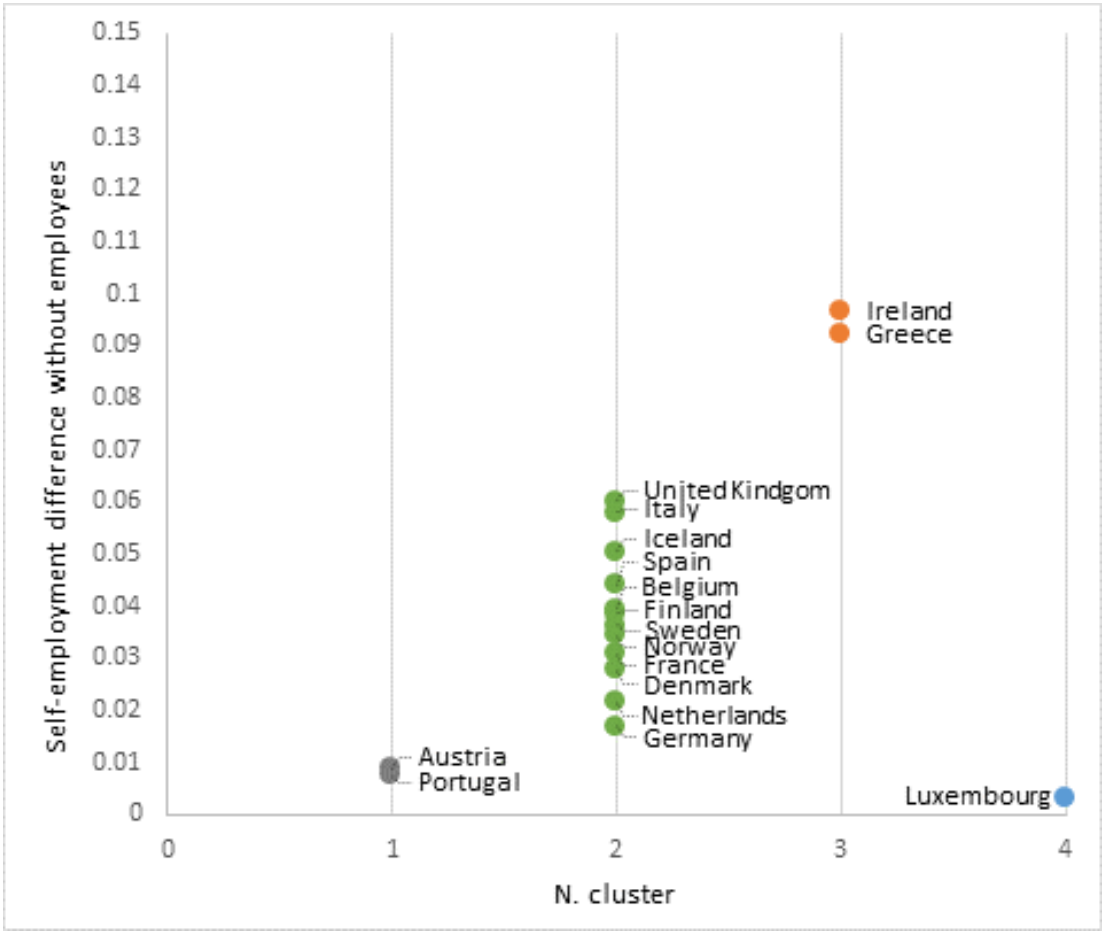


Comparing the results for the three cases in Figures 4-6 we observe that the clusters are fairly homogeneous, with only a few countries shifting between clusters. In general, we observe three main clusters: the core, the Southern countries and the Northern countries. Moreover, we should note the specific case of both Ireland and Greece. These countries have a large agriculture and livestock sector, which involves high self-employment rates and, in particular, a remarkable difference between male and female self-employment rates (the largest ones in the sample), as most farmers are men. The latter is well appreciated in the subsequent analyses.

In a next stage, we account for the relevance of different factors on self-employment. We then carry out the cluster analysis accounting for the (dis)similarities on total self-employment difference together with its main determinants (in contrast to the previous analysis reflected in Figures 4-6). The results are presented in Figure 7.

Figure 7: Clusters for difference male-female total self-employment + GPDpc + Primary

Education + Globalization+ Retirement

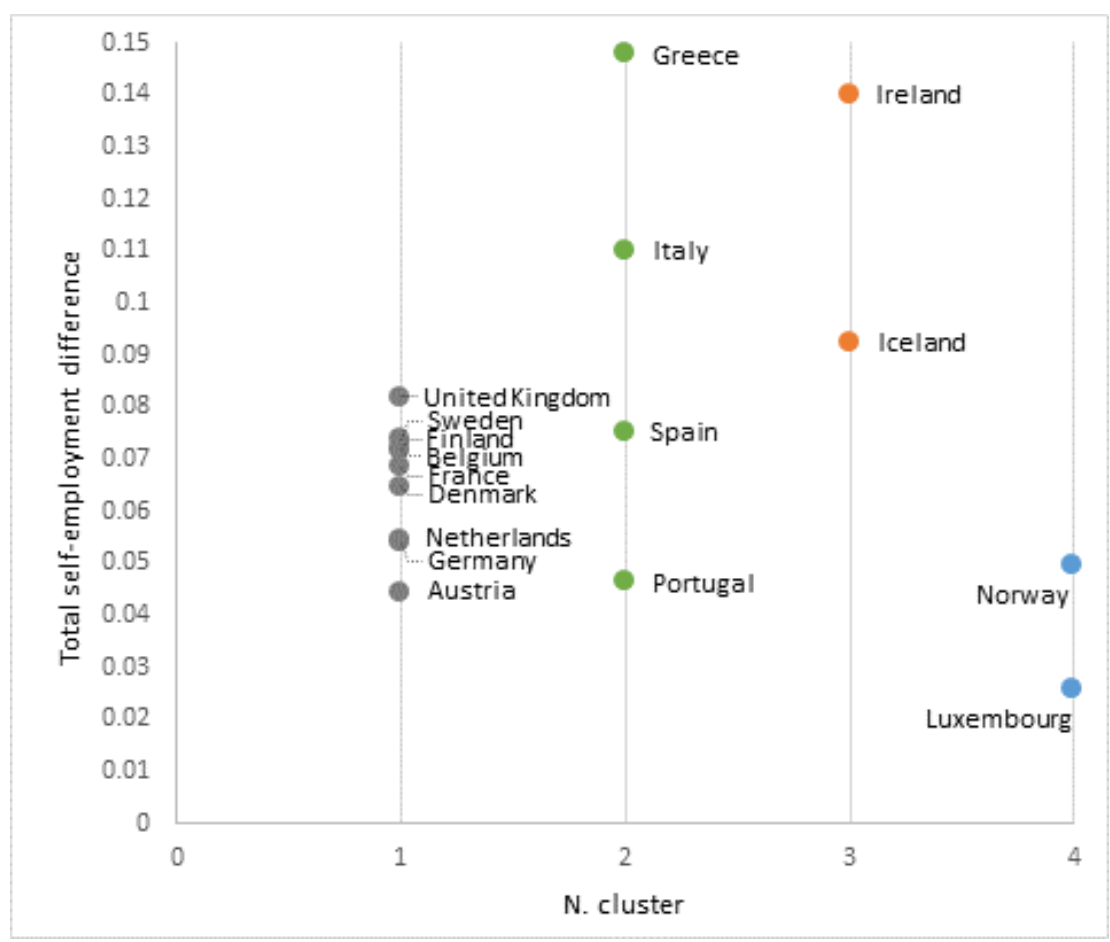


When forming groups of countries with similarities in terms of GDP per capita, educational attainment (primary level), globalization and retirement, four clusters are derived. The results evidence the difference between core and peripheral countries in Europe. Mediterranean countries (Greece, Italy, Portugal and Spain) form the group with the second largest difference ratios for self-employment, together with the lowest GDP per capita and the most aged population. At the opposite end, Luxembourg and Norway form a pair with the lowest difference ratio and the largest GDP per capita by far. The remaining countries are located in intermediate positions regarding the selected variables, with the exception of Iceland and Ireland; this pair shows the highest value for the difference ratio, joint with the highest educational attainment, lowest globalization degree and youngest population.

In this case, if primary education is substituted by tertiary education, Luxembourg and Norway present the largest educational attainment for this level, and Spain joins the group of core countries (this is the only novelty in cluster formation).

There is a notable distance between the self-employment ratios of Luxembourg and Norway, and the ones of the core countries. If we look closer to the values of the variables selected for forming clusters, the educational attainment for primary level is very similar in both clusters, followed by close values with respect to retirement and globalization; then, dissimilarities mainly come from GDP per capita.

Delving further into the differences between the two clusters with the largest selfemployment ratios and the two with the lowest ones, we have clear evidence: the latter displays the highest percentages of primary education as well as the lowest degrees of globalization. We also observe that core countries have, on average, larger GDP per capita but a slightly more aged population than the periphery; at this respect, we should highlight that the periphery 
contains the countries with the lowest retirement percentage (Ireland and Iceland) in the sample, as well as the more aged (Italy), i.e., they are quite heterogeneous in this sense.

When forming groups of countries with similarities in terms of GDP per capita, educational attainment (primary level), globalization, retirement, tax burden and internet access, four clusters are derived, as reflected in Figure 8.

Figure 8: Clusters for difference male-female total self-employment + GPDpc + Primary Education + Globalization + Retirement + Tax burden + Communications

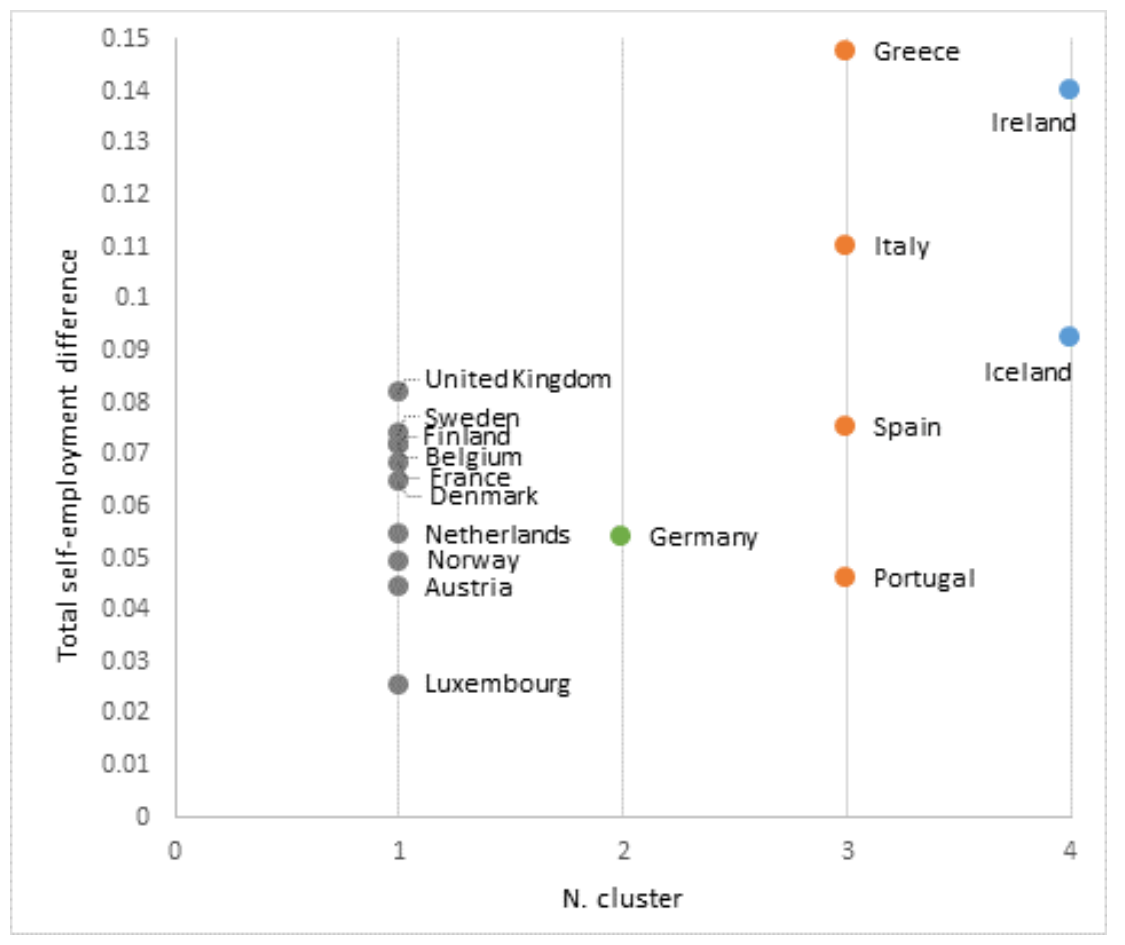

The results show the difference between core and peripheral countries in Europe. Greece, Italy, Portugal and Spain form the group with the second largest difference ratios for selfemployment, together with the lowest GDP per capita, the largest proportion of people with primary education, and the lowest penetration of internet; in addition, the population is quite aged and the globalization index is not as remarkable as in the core Europe. 
Interestingly, Germany belongs to a different cluster than the rest of core countries, which form a vast group (number 1); this may be due to their comparatively lower tax rates. The lower level of GDP per capita is noticeable, as well as educational attainment, and the notably more aged population of Germany compared to group $1 ;^{8}$ despite this fact, the difference ratio shows a slightly better value and it is the lowest one out of all countries. Greece, Italy, Portugal and Spain are in the same cluster, showing almost the largest difference ratios. The cluster with the largest different ratios is composed of the pair of countries with the least aged populations: Ireland and Iceland. The latter shows different levels, both negatively and positively, of the variables compared to the Mediterranean countries, but together present the largest ratios for the difference in self-employment.

Overall, our results are again consistent with Saridakis et al. (2019) for OECD European countries. As already mentioned, they find weak evidence of convergence across Europe, but stronger within predetermined regions. In particular, they evidence conditional convergence within Southern, Northern and Western Europe, whilst Central Europe shows mixed evidence. Moreover, our results resemble those of Monfort et al. (2013) regarding convergence in GDP, as they evidence clubs in the EU-14 panel linked to a "core-periphery" location.

Other variables such as the openness index and tertiary education attainment have also been included in the analysis, as well as other combination of variables; however, the results have been omitted to save space given that there were no significant differences from the clusters already obtained. In addition, similar results are found when obtaining the clusters using selfemployment with and without employees. All these results are available upon request.

\footnotetext{
${ }^{8}$ It is worth noting the role played by the reunification process in Germany. After that moment, a catching-up process is clear for East Germany, but it does not live for a long time (Schindele, 2010).
} 
In the Appendix we present the reports with descriptive statistics for the different cases under study; the graphical representations on the formation of groups (the so-called 'dendograms') are available on request to save space.

\section{Conclusions}

This paper analyses whether there is convergence in self-employment by gender in the European Union. This research is opportune and necessary given the European Union recognition of the importance of self-employment and its efforts to increase the number of entrepreneurs, and the lack of studies analysing the behavior and convergence of selfemployment rate difference between male and female entrepreneurs.

Theoretically, the paper presents a stylized macro model that provides macro-foundations of entrepreneurship in a simple framework. Empirically, it uses unit root tests, fractional integration and cluster analysis to assess convergence. We aim at finding evidence for two types of convergence: between genders and among European countries. The macro model suggests that the difference in self-employment between males and females is associated with the micro [individual choice] variables such as education and risk attitudes [captured by retirement preferences]. Macroeconomic variables such as total income [which captures business cycle and unemployment effects], income per capita, tax burden, infrastructure [proxy given by communications such as internet access], and globalization amplify them.

The time series analysis of convergence finds, in general, mixed evidence of convergence. From the cluster analysis we derive four groups of countries with similarities in terms of GDP per capita, educational attainment, globalization and retirement (and also when accounting for tax burden and communications). The results evidence the difference between core and peripheral countries in Europe. Mediterranean countries (Greece, Italy, Portugal and Spain) exhibit comparatively large values for the difference ratios of self-employment, together with 
lower GDP per capita and more aged populations than the remaining countries; Ireland and Iceland follow a similar pattern regarding most variables. At the opposite end of the spectrum, core and Northern countries show moderate or low difference ratios, together with relatively large values for the GDP per capita.

The cluster analysis evidences the influence on self-employment of the main factors pointed out in the theoretical framework. Going further, idiosyncratic (then, structural) components seem to be explaining the differences among countries, compared to usually referred to, cultural reasons. Thus, the role played by the different determinants, as well as the existing similarity between certain countries in terms of self-employment, are main questions that should be in the agenda of the policymakers. Several countries have the opportunity of narrowing the gap between male and female self-employment; those countries exhibiting a similar behavior should take advantage of their potential synergies. Eventually, as pointed out by Saridakis et al. (2019), fostering self-employment should foster economic growth (particularly in low-growth regions or during recessions), as it is becoming a major driver for the development of the economies and their innovative processes ${ }^{8}$. Although not directly tested and assessed, we can say that the evidence in favor of convergence may highlight that EU wide policies to enhance entrepreneurship may have worked, by means of homogenizing the way entrepreneurs behave.

The paper can be extended in several directions. Thus, for example, the possibility of structural breaks is an issue that should be taken into account, especially noting that part of the methodology used in the paper (based on unit roots and fractional integration) is very sensitive to the presence of breaks in the data (Diebold and Inoue, 2001; Granger and Hyung, 2004; Ohanissian et al., 2008; etc.). By considering breaking points, we can assess the effect of the economic crisis on entrepreneurship by gender from 2008, among other events. In addition,

\footnotetext{
${ }^{8}$ In the EU, the promotion of self-employment is reflected in the Europe 2020 Strategy.
} 
having this paper as a starting point, we could broaden the country sample by considering the most recent EU members, as some of them show significant levels of entrepreneurship according to their new business entry density (World Bank) and/or their total early-stage entrepreneurial activity (Global Entrepreneurship Monitor - GEM - reports). 


\section{APPENDIX}

Table A.1.: Report for Figure 4

\begin{tabular}{llccc}
\hline & & $\begin{array}{c}\text { Total self-employment } \\
\text { difference }\end{array}$ & $\begin{array}{c}\text { Self-employment difference } \\
\text { with employees }\end{array}$ & $\begin{array}{c}\text { Self-employment difference } \\
\text { without employees }\end{array}$ \\
\hline 1 & Mean & 0.0498 & 0.0362 & 0.0079 \\
& $\mathrm{~N}$ & 5 & 12 & 2 \\
& SD & 0.0045 & 0.0041 & 0.0010 \\
\hline 2 & Mean & 0.0750 & 0.0526 & 0.0383 \\
& $\mathrm{~N}$ & 8 & 2 & 12 \\
& SD & 0.0086 & 0.0024 & 0.0134 \\
\hline 3 & Mean & 0.1325 & 0.0223 & 0.0944 \\
& $\mathrm{~N}$ & 3 & 2 & 2 \\
& SD & 0.0199 & 0.0014 & 0.0030 \\
\hline 4 & Mean & 0.0256 & 0.0145 & 0.0031 \\
& $\mathrm{~N}$ & 1 & 1 & 1 \\
& SD & - & & 0.0392 \\
\hline Total & Mean & 0.0748 & 0.0352 & 17 \\
& $\mathrm{~N}$ & 17 & 17 & 0.0266 \\
\hline & SD & 0.0325 & 0.0099 & \\
\hline
\end{tabular}

Table A.2.: Report for Figure 5

\begin{tabular}{llccccc}
\hline & & Difference ratios & GDPpc & Prim_Education & KOF_index & Retirement \\
\hline 1 & Mean & 0.0651 & 33799.9939 & 28.2142 & 86.8859 & 16.4658 \\
& N & 9.0000 & 9.0000 & 9.0000 & 9 & 9 \\
& SD & 0.0118 & 4491.9629 & 4.7436 & 1.46368 & 1.28937 \\
\hline 2 & Mean & 0.0948 & 20890.3601 & 52.4524 & 79.6228 & 17.5899 \\
& N & 4.0000 & 4.0000 & 4.0000 & 4 & 4 \\
& SD & 0.0439 & 4593.3431 & 11.3918 & 1.65072 & 1.05007 \\
\hline 3 & Mean & 0.1161 & 34157.4325 & 36.5432 & 77.9137 & 11.6060 \\
& N & 2.0000 & 2.0000 & 2.0000 & 2 & 2 \\
& SD & 0.0336 & 3723.7921 & 4.5089 & 7.73663 & 0.36665 \\
\hline 4 & Mean & 0.0376 & 69039.6719 & 28.9445 & 84.2855 & 14.6187 \\
& N & 2.0000 & 2.0000 & 2.0000 & 2 & 2 \\
& SD & 0.0169 & 6467.6456 & 9.7707 & 0.58554 & 0.80832 \\
\hline Total & Mean & 0.0748 & 34950.3291 & 34.9831 & 83.8155 & 15.9412 \\
& N & 17.0000 & 17.0000 & 17.0000 & 17 & 17 \\
& SD & 0.0325 & 14595.5464 & 12.2372 & 4.40722 & 2.11883 \\
\hline
\end{tabular}


Table A.3.: Report for Figure 6

\begin{tabular}{llccccccc}
\hline & & GDPp & Prim Education & KOF index & Retirement & $\begin{array}{c}\text { Tax } \\
\text { burden }\end{array}$ & $\begin{array}{c}\text { Internet } \\
\text { access }\end{array}$ \\
\hline 1 & Mean & 0.060709035 & 41134.87046 & 28.99125154 & 86.4984 & 15.8547 & 25.1843 & 81.7321 \\
& $\mathrm{~N}$ & 10 & 10 & 10 & 10 & 10 & 10 & 10 \\
& SD & 0.016999645 & 15422.51037 & 5.062810685 & 1.75584 & 1.11586 & 3.35688 & 7.13074 \\
\hline 2 & Mean & 0.053887331 & 30930.5839 & 21.90390261 & 85.5599 & 18.8818 & 11.1541 & 81.6145 \\
& N & 1 & 1 & 1 & 1 & 1 & 1 & 1 \\
& SD & & & & & & \\
\hline 3 & Mean & 0.094784863 & 20890.36011 & 52.45239705 & 79.6228 & 17.5899 & 19.9287 & 55.3506 \\
& N & 4 & 4 & 4 & 4 & 4 & 4 & 4 \\
& SD & 0.043903246 & 4593.343091 & 11.39177713 & 1.65072 & 1.05007 & 3.63241 & 6.85245 \\
\hline 4 & Mean & 0.116089219 & 34157.4325 & 36.54318337 & 77.9137 & 11.6060 & 23.7925 & 81.6689 \\
& $\mathrm{~N}$ & 2 & 2 & 2 & 2 & 2 & 2 & 2 \\
& SD & 0.033615559 & 3723.792128 & 4.508941472 & 7.73663 & 0.36665 & 0.06693 & 13.62316 \\
\hline Total & Mean & 0.074840916 & 34950.32906 & 34.98308076 & 83.8155 & 15.9412 & 22.9586 & 75.5103 \\
& $\mathrm{~N}$ & 17 & 17 & 17 & 17 & 17 & 17 & 17 \\
& SD & 0.032541728 & 14595.54645 & 12.23723249 & 4.40722 & 2.11883 & 4.79585 & 13.48604 \\
\hline
\end{tabular}




\section{References}

Acs, Z. J. (2006). How is entrepreneurship good for economic growth? Innovations: Technology Governance Globalization, 1(1), pp. 97-107.

Andersson, P. and E. Wadensjö (2007). Do the Unemployed Become Successful Entrepreneurs? International Journal of Manpower, 28, pp. 604-626.

Baldassarini, A. (2015). Self-employment and the economic crisis in Europe. Social Situation Monitor Seminar on self-employment, 21 May.

Barro, R. J. and X. Sala-i-Martin (1991). Convergence across states and regions. Brookings Papers on Economic Activity, 1, pp.107-82.

Bendick, M. and M. L. Egan (1987). Transfer payment diversion for small business development: British and French experience. Industrial and Labor Relations Review, 40, pp. $528-542$.

Bernard, A. B. and S. N. Durlauf (1995). Convergence in international outputs. Journal of Applied Econometrics, 10, pp. 97-108.

Block, J., Colombo, M., Cumming, D. and S. Vismara (2018). New players in entrepreneurial finance and why they are there. Small Business Economics, 50, pp. 239-250.

Boudreaux, C. J. (2017). Institutional quality and innovation: Some cross-country evidence. Journal of Entrepreneurship and Public Policy, 6, pp. 26-40.

Brown, S., Farrell, L., Harris, M. and J. Sessions (2006). Risk preference and employment contract type. Journal of the Royal Statistical Society, Series A, 169, pp. 849-863. 
Caliendo, M., Hogenacker, J., Künn, S. and Wiessner, F. (2015). Subsidized start-ups out of unemployment: A comparison to regular business start-ups. Small Business Economics, 45(1), 165-190.

Cumming, D., Johan, S. and M. Zhang (2014). The Economic Impact of Entrepreneurship: Comparing International Datasets. Corporate Governance: An International Review, 22, pp. $162-178$.

Dawson, C., Henley, A. and P. Latreille (2014). Individual Motives for Choosing Selfemployment in the UK: Does Region Matter? Regional Studies, 48(5), pp. 804-822.

Dickey, D.A and Fuller, W. A. (1979). Distributions of the estimators for autoregressive time series with a unit root. Journal of American Statistical Association, 74 (366), 427-481.

Diebold F. X. and A. Inoue, A. (2001). Long memory and regime switching. Journal of Econometrics 105, 131-159.

Diebold, F. X. and G.D. Rudebusch (1991). On the power of Dickey-Fuller tests against fractional alternatives. Economics Letters, 35, 155-160.

Dunn, T. and D. Holtz-Eakin (2000) Financial capital, human capital and the transition to selfemployment: Evidence from intergenerational links. Journal of Labor Economics, 18, pp. 282-305.

Evans, D. S. and L.S. Leighton (1989). Some empirical aspects of entrepreneurship. American Economic Review, 79, pp. 519-535.

Faria, J. R. (2015). Entrepreneurship and business cycles: Technological innovations and unemployment, International Entrepreneurship and Management Journal, 11, pp. 253265. 
Faria, J. R., Cuestas, J. C. and L. A. Gil-Alana (2009). Unemployment and entrepreneurship: A cyclical relationship?, Economics Letters, 105, pp. 318-320.

Faria, J. R., Cuestas, J. C. and E. Mourelle (2010). Unemployment and entrepreneurship: A cyclical relationship? Economic Modelling, 27, pp. 1282-1291.

Faria, J. R. and Z. Wu (2012). From unemployed to entrepreneur: The role of absolute bequest motive. Economics Letters, 114, pp. 10-123.

Faria, J. R. and P. McAdam (2013). Anticipation of future consumption: A monetary perspective. Journal of Money Credit and Banking, 45, pp. 423-447.

Fernandes, C., Raposo, M., Ferreira, J., Thurik, R. and J. Faria (2015). Entrepreneur location decisions across industries. International Entrepreneurship and Management Journal, 12, pp. $985-1006$.

Ferreira, J. J. and C.I. Fernandes (2015). Entrepreneurship and Location: The Cultural Differences Between Two Countries, in Peris-Ortiz, M and Merigó-Lindahl, J. (Eds.), Entrepreneurship, Regional Development and Culture, Springer, New York.

Fondeville, N., Ozdemir, E., Lelkes, O. and T. Ward (2015). Recent changes in selfemployment and entrepreneurship across the EU. Research note No. 6/2015.

Friedman, M. (1957). The Permanent Income Hypothesis. A Theory of the Consumption Function. Princeton University Press. Princeton, USA.

Fritsch, M. A., Kritikos, S. and A. Sorgner (2015). Why Did Self-Employment Increase so Strongly in Germany? Entrepreneurship and Regional Development, 67, pp. 307-333. 
Gil-Alana, L.A. and P.M. Robinson (1997). Testing of unit roots and other nonstationary hypothesis in macroeconomic time series. Journal of Econometrics, 80, 2, pp. 241-268.

Goel, R. K. and D. Göktepe-Hultén (2013). Nascent entrepreneurship and inventive activity: a somewhat new perspective. Journal of Technology Transfer, 38, pp. 471-485.

Goel R. K. and R. Ram (1994). Research and development expenditures and economic growth: a cross-country study. Economic Development and Cultural Change, 42, pp. 403-412.

Goetz, S. J., Fleming, D. A. and A. Rupasingha (2012). The Economic Impacts of SelfEmployment. Journal of Agricultural and Applied Economics, 44(3), pp. 315-321.

Gong G. and W. Keller (2003). Convergence and polarization in the global income levels: a review of recent results on the role of international technology diffusion. Research Policy, 32, pp. 1055-1079.

Granger, C. W. J. and N. Hyung (2004). Occasional structural breaks and long memory with an application to the S\&P 500 absolute stock returns. Journal of Empirical Finance 11, 399421.

Hassler, U. and J. Wolters (1994). On the power of unit root tests against fractional alternatives. Economics Letters, 45, pp. 1-5.

Hatfield, I. (2015). Self-employment in Europe, Report (UK: Institute for Public Policy Research (IPPR)).

Henrekson, M. and T. Sanandaji (2014). Small business activity does not measure entrepreneurship. Proceedings of the National Academy of Sciences, Feb 4; 111(5): pp. $1760-1765$. 
Henrekson, M. and T. Sanandaji (2019). Measuring Entrepreneurship: Do Established Metrics Capture High-Impact Schumpeterian Entrepreneurship? Entrepreneurship Theory and Practice, forthcoming.

Holtz-Eakin, D., Joulfaian, D. and H. S. Rosen (1993). The Carnegie conjecture: some empirical evidence. Quarterly Journal of Economics, 108, pp. 413-435.

Joulfaian, D. and M. O. Wilhelm (1994). Inheritance and labor supply. Journal of Human Resources, 29, pp. 1205-1234.

Knight, F. K. (1921). Risk, Uncertainty and Profit. Houghton Mifflin, New York.

Koellinger, P. D. and A. R. Thurik (2012). Entrepreneurship and the business cycle. Review of Economics and Statistics, 94, pp. 1143-1156.

Lee, D. and P. Schmidt (1996). On the power of the KPSS test of stationarity against fractionally integrated alternatives. Journal of Econometrics, 73, pp. 285-302.

Minniti, M. and M. Lévesque (2010). Entrepreneurial types and economic growth. Journal of Business Venturing, 25, pp. 305-314.

Monfort, M., Cuestas, J. C. and J. Ordóñez (2013). Real convergence in Europe: a cluster analysis. Economic Modelling, 33, pp. 689-94.

Monteiro, G. and S. J. Turnovsky (2016). Anticipated consumption and its impact on capital accumulation and growth. International Journal of Economic Theory, 12, pp. 203-232.

Nittykangas, H. and H. Tervo (2005). Spatial variations in intergenerational transmission of self-employment. Regional Studies, 39, pp. 319-332. 
Ng, S. and P. Perron (2001). Lag selection and the construction of unit root tests with good size and power. Econometrica, 69, pp. 1519-1554.

Parker, S. (2018). Economics of Entrepreneurship. Cambridge University Press (second edition), Cambridge.

Ohanissian, A., Russell, J. R. and R. S. Tsay (2008). True or spurious long memory? A new test. Journal of Business, Economics and Statistics 26(2), pp. 161-175.

Perron, P. (1989). The great crash, the oil price shock and the unit root hypothesis. Econometrica, vol. 57, pp. 1361-1401

Phillips, P.C.B. and P. Perron (1988). Testing for a unit root in time series regression, Biometrika 75, 335-346.

Prachowny, M. (1993). Okun's Law: Theoretical Foundations and Revised Estimates. Review of Economics and Statistics, 75, pp. 331-336.

Saridakis, G., Mendoza Gonzalez, M. A., Muñoz Torres, R. I. and C. Hand (2019). Do Selfemployment Rates Converge? Evidence from European OECD Countries. Journal of Common Market Studies, 57(3), pp. 551-562.

Schindele, Y. (2010). How long does it take to become an entrepreneurial society: The case of German convergence in self-employment, Jena Economic Research Papers No. 2010015, Friedrich-Schiller-University Jena.

Schumpeter, J. A. (1934). The theory of economic development. Cambridge: Harvard University Press. 
Shaver, K. G. and Scott, L. R. (1991). Person, Process, Choice: the psychology of new venture creation. Entrepreneurship Theory and Practice, 16(2), pp. 23-45.

Svaleryd, H. (2014). Self-employment and the local business cycle. Small Business Economics, 44, pp. $55-70$.

Terjensen, S., J. Hessels and D. Li (2016). Comparative international entrepreneurship: A review and research agenda. Journal of Management, 42, pp. 299-344.

Thurik, A. R. (2009). Entreprenomics: entrepreneurship, economic growth and policy. In Z. J. Acs, D. B. Audretsch, \& R. Strom (Eds.), Entrepreneurship, growth and public policy (pp. 219-249). Cambridge: Cambridge University Press.

van Stel A., M. Carree, and A. R. Thurik (2005). The effect of entrepreneurial activity on national economic growth, Small Business Economics Journal, 24, pp. 311-321.

Verheul, I., Van Stel, A. and R. Thurik (2006). Explaining female and male entrepreneurship at the country level. Entrepreneurship \& Regional Development, 18(2), pp. 151-183.

Weixel, A. (2014). Womentrepreneurship after the Great Recession: An Empirical Analysis of Female Entrepreneurship Rates in Europe. CMC Senior Theses, Paper 968.

Wennekers S., and A. R. Thurik (1999). Linking entrepreneurship and economic growth. Small Business Economics Journal, 13, pp. 27-56. 